\title{
THE IMPORTANCE OF EXCISES FOR THE FISCAL BALANCE IN THE REPUBLIC OF SERBIA
}

\author{
Branimir Kalaš \\ University of Novi Sad, Faculty of Economics in Subotica, Serbia \\ branimir.kalas@ef.uns.ac.rs
}

\section{Original Scientific Paper 10.5937/jouproman9-29601}

\begin{abstract}
Excises are one of the most generous taxes in the Republic of Serbia and this tax form should be determined at adequately level in order to provide positive effect on the economy. The aim of this paper is to investigate the relationship between excises and fiscal balance in the Republic of Serbia for the period 2008-2019. Empirical research includes descriptive statistics, VAR model and Granger causality test in order to determine their relationship. Results of the paper show that excises have significant and positive effect on fiscal balance and there is unidirectional causality from excises to fiscal balance in the analyzed period.
\end{abstract}

Keywords: excises, fiscal balance, VAR model, Republic of Serbia

\section{Introduction}

Taxes as instruments of fiscal policy in modern economies are often used in acting to change the economic structure. Taxes can have multiple effects on the economic structure, as follows: capacity allocation, faster or slower development of certain branches, dislocation and change of production structure, to change the employment structure, redirection of demand from imported to domestic product, to effect on product price structure, fiscal benefits which leads to faster or slower development of industries (Vukša et al. 2013).

Tax systems of modern economies differ from each other from the aspect of constituent elements and tax share (Aničić et al. 2012). Taxes are the most essential public revenue of all modern states (Stojanović, Đorđević, 2016). For every country it is important to have tax system that will continuously collect revenues and use for covering different social needs (Đorđević, Perović, 2016). Kalaš et al. (2017) determined tax policy as one of the most important segemnts of economic policy whereas its relevance is reflected through the taxation process and the generation of public revenues. Taxes have a core role and place in the economy and they should be determined at an optimum level in order to enable economic prosperity (Kalaš et al. 2018).

In modern conditions of high fiscal burden, the budget deficit policy has become a tool for stimulating economic activity (Ćurčić, 2016). However, a permanent and high budget deficit can lead to instability if not financed in a timely and appropriate way, which all leads to the public debt growth (Stanulović, 2017). The solution to the budget deficit problem should be sought in the reduction of publi expenditures, but also in the better conception of public revenues (Baturan and Cvjetkovic, 2016). Aničić and Aničić (2019) highlight that a growth model based on the service sector and the growth of individual consumption was implemented in our country durign the transition process. Having in mind the importance of the consumption component, it is necessary to point out indirect taxation. Consumption taxes provide significant budget revenues and have an important place in the tax systems of modern economies (Đorđević, 2014). 
Obadić et al (2014) noticed that in countries with tax systems dominated by indirect taxes, reduction of the trade deficit would lead to budget deficit growth.

\section{Theoretical background about excises}

Excises are specific taxes that tax the consumption of mainly monopolistic products with low demand elasticity (Stojković, 2014). The unfairness of the regressive effect of excises can best be illustrated by the example of energy sources since the demand for these products is quite inelastic (Bačanin, 2018). Excises presents selected taxes paid on the consumption of certain products, where the objectives of implementation of the excises are different: regulation of externalities, redistribution of tax burden and collection of additional tax revenues (Arsić and Ranđelović, 2017). David (2018) highlighted taxes as an important and suitable instrument for the consumption reduction of the harmful products such as tobacco. Laković et al. (2019) found that an increase in excises could be a very efficient tool in reducing the adverse impact on houslehold member's health, productivity and budget. Accordingly, Luong and Vu (2020) argue that excises are defined for specific goods and services that are not encouraged due to their negative implications on health.

In addition to generosity, the advantages of excises are reflected in (Jović, 2018):

- effects on reducing the consumption of certain products such as cigarettes and alcoholic beverages;
- redistribution of income (when luxury goods are taxed) and reducing the regressivity of consumption tax;

- effects on consumer behavior and choice in terms of product substitution.

On the other hand, the bad sides of this tax form are manifested in (Jović, 2018):

- when a specific excises is determined, the cheaper products are relatively more burdened which leads to a regressive impact;

- calculated at the moment of production or import that means that the economy credits the fiscus until the moment of product consumption;

- can cause negative implications for product competitiveness.

Bisić and Ranđelović (2018) suggested that countries in Western Balkan should focus to improvement of efficiency of tax enforcement institutions in order to mitigate the risk of growing the shadow economy.

\section{Analysis of excises trend in the Republic of Serbia}

In order to investigate the relationship between fiscal balance and excises, it is necessary to analyze their trends. Firstly, there is trend of fiscal balance, as well as, excises from the aspect of absolute and relative trend and percentage share in total tax revenues in the Republic of Serbia for the period 2008-2019. 
Figure 1. Fiscal balance in the Republic of Serbia

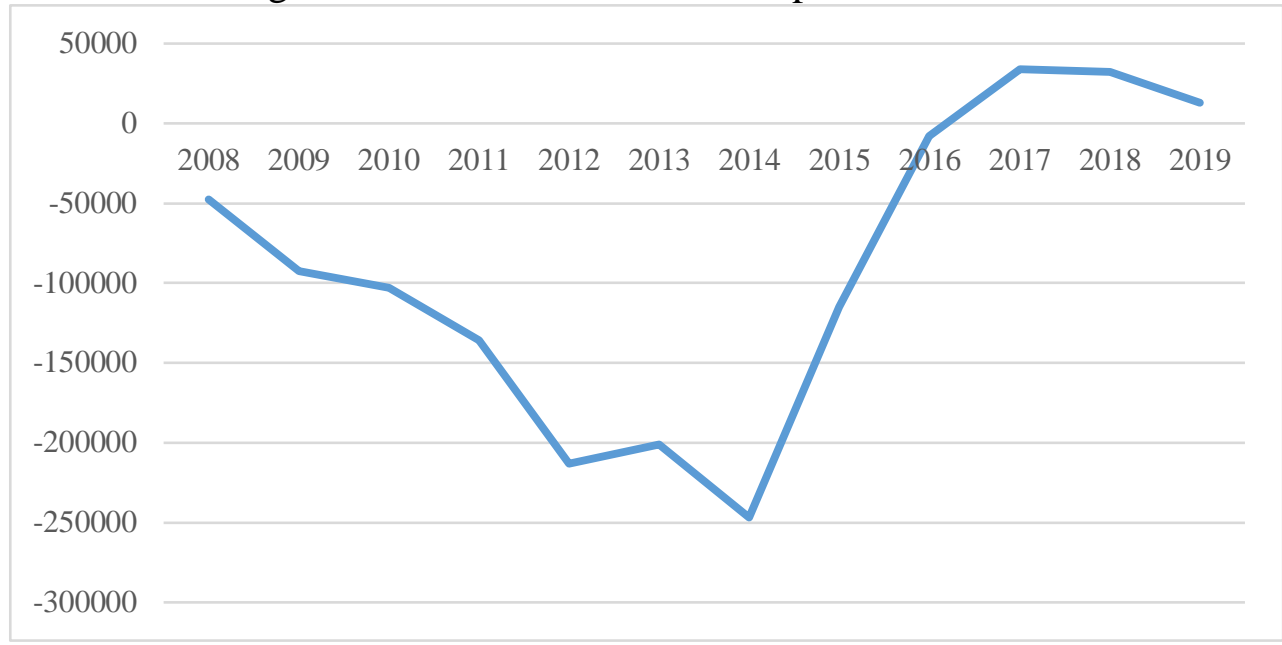

Source: Author based on https://www.mfin.gov.rs/en/documents/macroeconomic-and-fiscal-data/

Figure 1. shows that fiscal balance is negative from 2008 to 2016, where in last three years the government of the Republic of Serbia has achieved positive value of this indicator and recorded surplus in the budget. This is a result of implemented fiscal consolidation programme that started in 2014 with the aim to reduce high level of budget deficit.

Figure 2. Excises - absolute trend



Source: Author based on https://www.mfin.gov.rs/en/documents/macroeconomic-and-fiscal-data/

Figure 2 manifests absolute trend of excises in the Republic of Serbia from 2008 to 2019, where revenues of this tax form has increased during the whole period. The analysis shows that revenues of excises increased by 205.909 million dinars from 2008 to 2019, where it is recorded the highest level of these revenues. 
Figure 3. Excises - relative trend



Source: Author based on https://www.mfin.gov.rs/en/documents/macroeconomic-and-fiscal-data/

Based on Figure 3, it can see that average annual growth rate of excises is $10.05 \%$ for the period 2008-2019 in the Republic of Serbia. Also, results of analysis show that the highest growth rate was 2009 and 2012, when excises increased by $19.07 \%$ and $18.51 \%$. On the other hand, the smallest growth rate is identified in 2008 $(2.05 \%)$. It is necessary point out that positive trend in revenues from excises is encouraging data, since this tax form are one of the two most generous revenues in the Republic of Serbia in addition to value added tax.

Figure 4. Share in total tax revenue

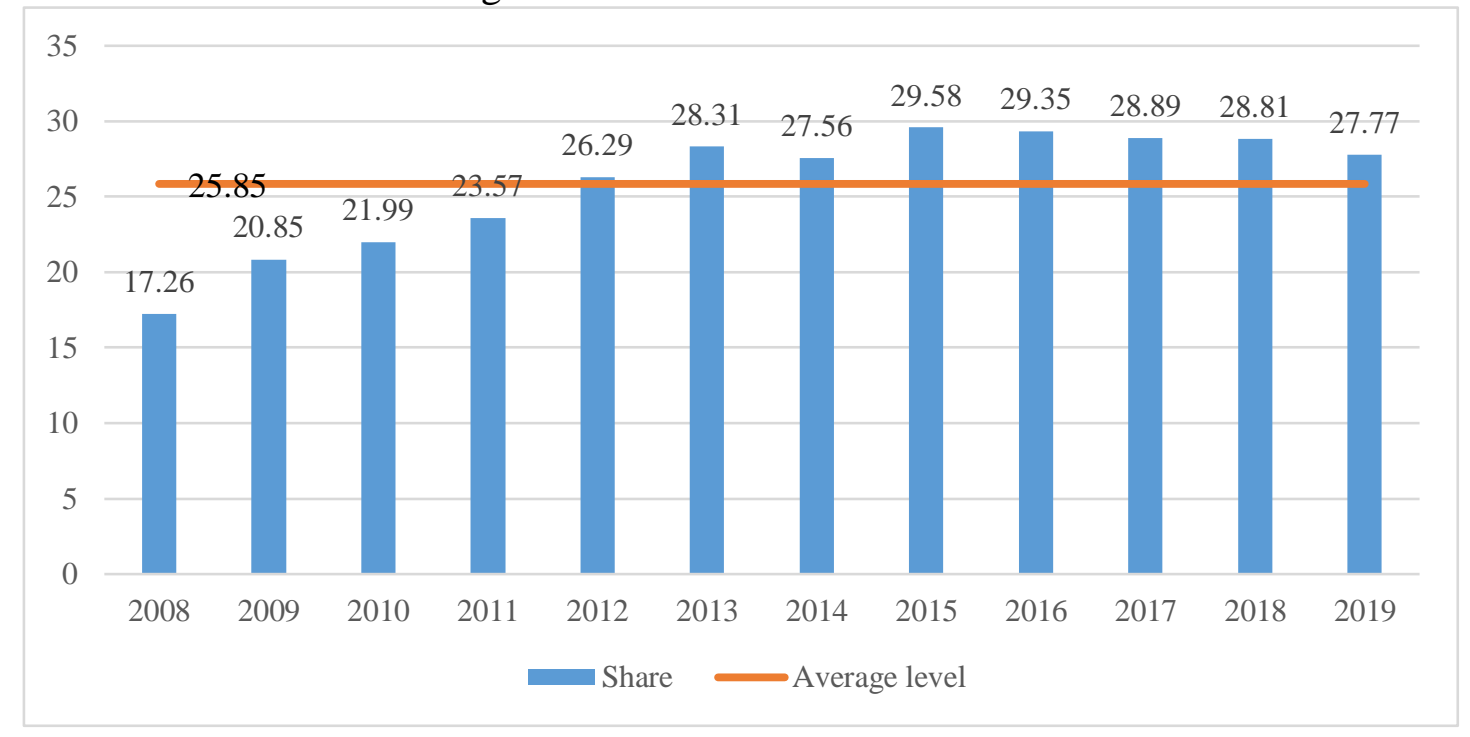

Source: Author calculation based on https://www.mfin.gov.rs/en/documents/macroeconomic-andfiscal-datal 
After presenting absolute and relative trend of excises in the Republic of Serbia, Figure 4 shows percentage share of this tax form in total tax revenues from 2008 to 2019. The average percentage share of excises is $25.85 \%$ of total tax revenues which implies that excises revenues contain about a third of total tax revenues. The highest share is recoded in 2015 $(29.35 \%)$, while the smallest share was in $2008(17.26 \%)$.

\section{Empirical results}

This part of research includes descriptive statistics of selected variables (fiscal balance and excises) for the period 20082019 in the Republic of Serbia. Also, there is VAR modelling with impulse-response function in order to determine potential relationship between fiscal balance and excises as one of the most important tax forms in our country.

Table 1. Descriptive statistics

\begin{tabular}{|l|c|c|}
\hline Variable & FB & EXC \\
\hline Mean & -90316.17 & 206602.5 \\
\hline Median & -97784 & 208617.5 \\
\hline Maximum & 33914 & 306546 \\
\hline Minimum & -246861 & 100627 \\
\hline Std. Dev. & 97393.63 & 69771.24 \\
\hline Skewness & -0.171106 & -0.062172 \\
\hline Kurtosis & 1.772341 & 1.689628 \\
\hline Jarque-Bera & 0.812127 & 0.866268 \\
\hline Probability & 0.666268 & 0.648473 \\
\hline
\end{tabular}

Source: Author calculation

Table 1 shows descriptive analysis of fiscal balance and excises from 2008 to 2019 in the Republic of Serbia. The mean value of fiscal balance is -90316.17 , while average reveneus from excises are 206602.5 for the analyzed period. The maximum value of fiscal balance is recorded in 2017, where fiscal balance was positive (surplus), while its minimum value was -246861 in 2014. Analyzing excises by maximum and minimum values, the highest level of revenues is identified at the end of period (306546), while the smallest revenues from excises was in 2008 (100627).

Table 2. VAR model

\begin{tabular}{|c|c|c|}
\hline Variable & $\begin{array}{c}\text { Fiscal } \\
\text { balance }\end{array}$ & Excises \\
\hline \multirow{3}{*}{$\begin{array}{l}\text { Fiscal } \\
\text { balance }(-1)\end{array}$} & 1.0655 & 0.0026 \\
\hline & 0.4306 & 0.0561 \\
\hline & 2.4746 & 0.0474 \\
\hline \multirow{3}{*}{$\begin{array}{l}\text { Fiscal } \\
\text { balance (-2) }\end{array}$} & 0.5384 & 0.0215 \\
\hline & 0.4257 & 0.0554 \\
\hline & 1.2646 & 0.3885 \\
\hline \multirow[t]{3}{*}{ Excises (-1) } & 2.7405 & 0.8024 \\
\hline & 3.6897 & 0.4801 \\
\hline & 0.7428 & 1.6715 \\
\hline \multirow[t]{3}{*}{ Excises (-2) } & 3.1546 & 0.1787 \\
\hline & 3.5527 & 0.4623 \\
\hline & 0.8879 & 0.3866 \\
\hline $\bar{C}$ & 69.3936 & 23.2471 \\
\hline R-squared & 0.8094 & 0.9893 \\
\hline $\begin{array}{l}\text { Adj. R- } \\
\text { squared }\end{array}$ & 0.6571 & 0.9807 \\
\hline F statistic & 5.3098 & 16.3813 \\
\hline Akaike AIC & 25.2290 & 21.15041 \\
\hline Schwarz SC & 25.3803 & 21.3017 \\
\hline
\end{tabular}

Source: Author calculation

The results from Table 2 show that excises (EXC) are statistically significant for fiscal balance (FB) for the observed period. Namely, the previous FB has a positive and significant effect on current FB. Finally, the impact of EXC shock on FB is positive and significant where value of Adj. R-squared is 0.66 , which means that VAR model explains $66 \%$ variations of explanatory variables. 
Figure 4. IRF function
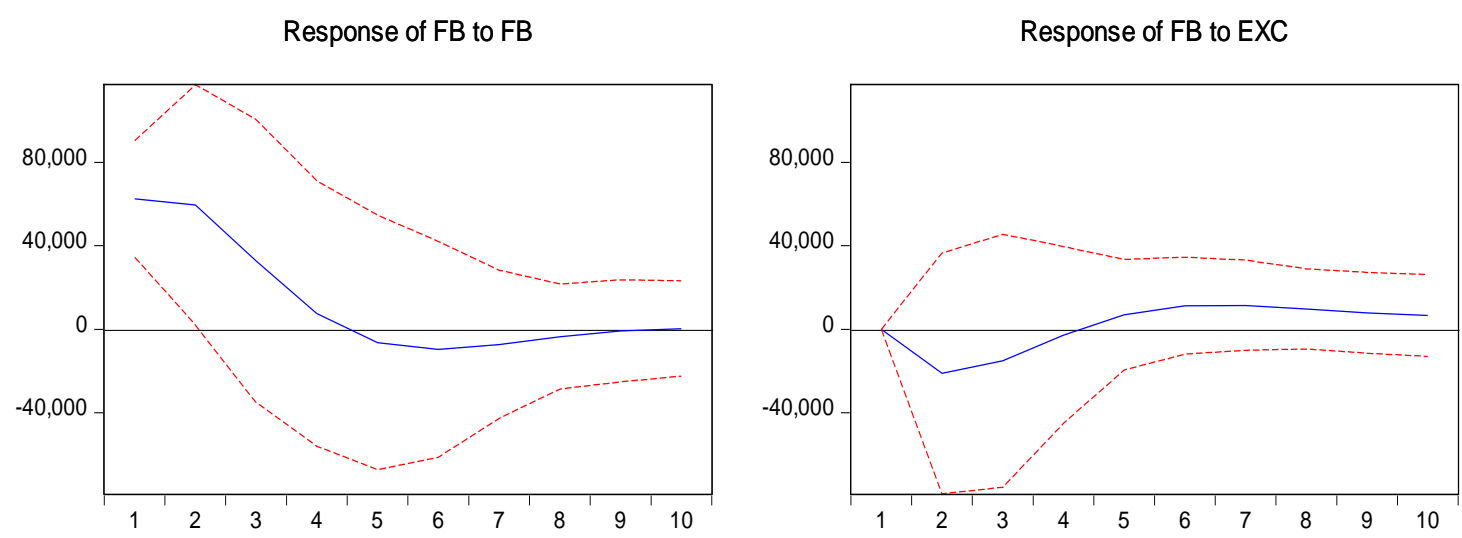

Response of EXC to FB

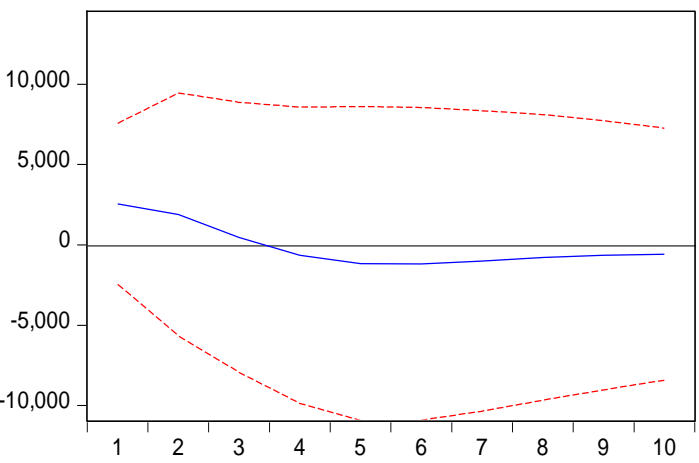

Response of EXC to EXC

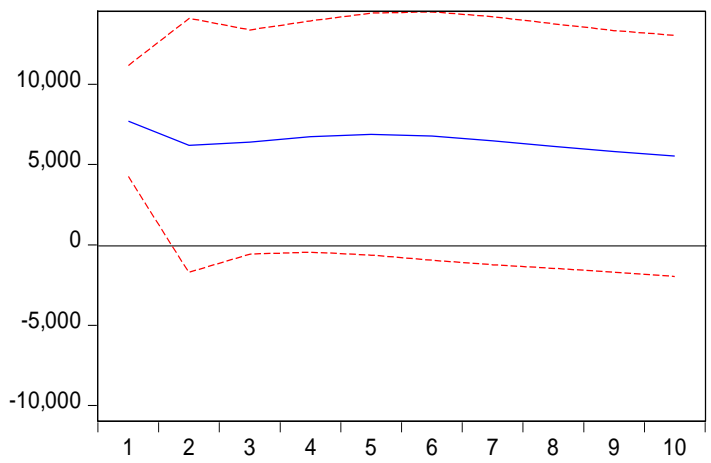

Source: Author calculation

Figure 4 shows impulse response function of fiscal balance (FB) in terms of change of excises (EXC) in the Republic of Serbia. The analysis of IRF reflects that change in excises (EXC) causes positive fiscal balance $(\mathrm{FB})$ response until the third period, while negative effects are minimized in nine and ten period.

Table 3. Causality test

\begin{tabular}{|l|l|l|l|}
\hline Direction & Obs & F-stat & Prob. \\
\hline$E X C \rightarrow F B$ & 10 & 0.57 & 0.003 \\
\hline$F B \rightarrow E X C$ & 10 & 0.74 & 0.770 \\
\hline
\end{tabular}

Source: Author calculation

Table 3 presents causality between excises and fiscal balance in the Republic of Serbia for the period 2008-2019. Results show unidirectional causality from excises to fiscal balance in the observed period.

\section{Conclusion}

The research paper has examined the relationship between fiscal balance and excises in the Republic of Serbia for the period 2008-2019. Empirical analysis includes VAR models where fiscal balance (FB) is defined as dependent variable, while excises (EXC) is independent variable. Results of VAR model show that shock in excises revenues (EXC) has positive and significant impact on fiscal balance (FB). Results of impulse response function confirm that increase in excises causes positive effects on fiscal balance in first three periods. 
Results of Granger test reflects that there is unidirectional causality from excises to fiscal balance in the observed period. It means that policymakers should increase revenues of this tax form in order to provide higher level of fiscal balance. The contribution of this paper enables information support to policymakers in the Republic of Serbia about importance of excises and potential implications to fiscal balance. Empirical results show that higher level of revenues from excises provide positive effect to fiscal balance in the Republic of Serbia.

\section{References}

Aničić, J., Laketa, M., Radović, B., Radović, D., \& Laketa, L. (2012). Tax policy of Serbia in the function of developing the economic system. UTMS Journal of Economics, 3(1), 33-43.

Aničić, J., Aničić, D. (2019). Which model of economic development is the best for Serbia. Journal of Process Management. New Technologies, 7(4), 46-56.

Arsić, M., Ranđelović, S. (2019). Ekonomija oporezivanja - teorija $i$ politika. Centar za izdavačku delatnost, Ekonomski fakultet, Beograd.

Bačanin, V. (2018). Ekološke uloge akciza u srpskom poreskopravnom sistemu, Ekonomski signali, 13(1), 1-15.

Baturan, L., Cvjetkovic, C. (2016). Excise duty on sweetened drinks in Serbia. Zbornik radova Pravnog fakulteta, Novi Sad, 50(3), 923-935.

Bisić, M., Ranđelović, S. (2018). Cigarette excise tax policy in the Western Balkans: Trends, effects and challenges. Ekonomika preduzeća, 66 (5-6), 320-332.

Ćurčić, M. (2016). Budget deficit of the Republic of Serbia. Oditor, 2(2), 51-58.

David, P. (2018). Do the V4 countries follow the European deficit? Evidence of Tobacco Taxes. Ekonomicky časopis, 66(3), 250-267

Đorđević, M. (2014). (Im)possibilities of revenue increase from consumption taxes in the tax system of Serbia. Teme, 38(3), 1155-1171.
Đorđević, M., Perović, D. (2016). An analysis of consumption taxes regressive effects. Teme, 40(4), 1399-1420.

Jović (2018) Poreski sistem i politika oporezivanja - teorija $i$ praksa. Visoka poslovna škola strukovnih studija Novi Sad.

Kalaš, B., Mirović, V., Andrašić, J. (2017) Struktura poreza u Republici Srbiji, Finansije, (16), 7-18.

Kalaš, B., Mirović, V., Milenković, N. (2018). The relationship between taxes and economic growth: Evidence from Serbia and Croatia. The European Journal of Applied Economics, 15(2), 17-28.

Laković, T., Mugoša, A., Čizmović, M., \& Radojević, G. (2019). Impact of Taxation Policy on Household Spirit Consumption and Public-Finance Sustainability. Sustainability, 11(20), 1-15. doi: 10.3390/su11205858.

Luong, L. \& Vu, L.H. (2020). Impacts of Excise Taxation on Non-Alcoholic Beverage Consumption in Vietnam. Sustainability, 12(3), 1-13. doi: 10.3390/su12031092.

Obadić, A., Globan, T., Nadoveza, O. (2014). Contradicting the twin deficits hypothesis: The role of tax revenues composition. Panoeconomicus, 61(6), 653-667.

Stanulović, M. (2017). Problem budžeskog deficit u savremenim ekonomijama. Ekonomija teorija $i$ praksa, 10(1), 27-43.

Stojanović, M., Đorđević, M. (2016). The role of environmental taxes in Serbian tax system. Ekonomika, 62(4), 75-84.

Stojković, A. (2014). The place and role of the excises in contemporary tax systems. Bizinfo, 5(1), $1-18$.

Vukša, S., Dinčić, M., Ristić, Ž., Belokapić, P. (2013). Poreski i carinski sistem i politika. Etnostil, Beograd. 